\title{
Democratic Backsliding in the European Union
}

Nick Sitter ${ }^{1}$ and Elisabeth Bakke ${ }^{2}$

Prepared for the Encyclopedia of European Union Politics (Nick Sitter gratefully acknowledges support from the European Union's Horizon 2020 research and innovation programme under grant agreement No 649484)

This is a draft of a chapter that has been accepted for publication by Oxford University Press in the forthcoming book The Oxford Encyclopedia of European Union Politics, edited by Finn Laursen, due for publication in 2019.

In advance of publication, the article will be available on-line as part of the Oxford Research Encyclopedia of Politics, Sitter, N., \& Bakke, E. (2019), "Democratic Backsliding in the European Union", Oxford Research Encyclopedia of Politics.

https://oxfordre.com/politics/view/10.1093/acrefore/9780190228637.001.0001/acrefore9780190228637-e-1476.

\section{Abstract}

Democratic backsliding in European Union member states is not only a policy challenge for the EU, but also a potential existential crisis. If the EU does too little to deal with member state regimes that go back on their commitments to democracy and the rule of law, this risks undermining the EU from within. On the other hand, if the EU takes drastic action, this might split the EU. This chapter explores the nature and dynamics of democratic backsliding in EU member states, and analyses the EU's capacity, policy tools and political will to address the challenge. Empirically it draws on the cases that have promoted serious criticism from the Commission and the European Parliament: Hungary, Poland, and to a lesser extent, Romania.

Keywords

Democratic Backsliding, Rule of Law, Populism, EU Crisis Management

Democratic backsliding began to look like a potential problem for the European Union only two years after the eastern enlargement of 2004. The eight post-communist states that were admitted to the EU on May $1^{\text {st }}$ that year had all passed the democracy test laid down in the Copenhagen Criteria of June 1993: they were all deemed to be liberal democracies, to respect human rights, to have a functioning market, and to be capable of implementing the Acquis Communautaire. But when Viktor Orbán's Fidesz party responded to losing the 2006

\footnotetext{
${ }^{1}$ BI Norwegian Business School and Central European University

${ }^{2}$ University of Oslo
} 
Hungarian elections by questioning their legitimacy, it brought into question the minimal criteria for democratic consolidation - that all major players accept the rules of the game.

By 2019, the EU has faced three clear cases of democratic backsliding among its member states. The EU's first real backsliding crisis began in 2010, when the landslide election in Hungary gave Fidesz a two-thirds majority and the power unilaterally to change the constitution. Over the next four years, the new government took control over the economy, the media, the courts, and the electoral process, thereby securing new super-majorities in the 2014 and 2018 elections. The second crisis came from the left, in 2012, when Victor Ponta's Social Liberal Union (USL) government in Romania accused president Traian Băsescu (from the centre-right Justice and Truth Alliance, DA) of abuse of power. The parliament impeached the president, but the ensuing referendum on Băsescu's removal failed because of low turnout and the Constitutional Court consequently invalidated the impeachment. Commission President José Manuel Barroso, Council President Herman Van Rumpoy, and Justice Commissioner Viviane Reding all deemed it necessary to intervene. Barroso summoned Ponta to Brussels on the eve of the referendum, where he duly secured the Romanian prime minister's commitment to meet all the EU's demands concerning the need to respect the rule of law and judicial independence (Politico 2012). Three years later, when the right-populist Law and Justice party (PiS) won the October 2015 elections in Poland and embarked on a Fidesz-style purge of the judiciary, democratic backsliding had become a well-established concept among journalist and politicians as well as academics in the European Union.

By 2019, backsliding had developed into a crisis that could threaten the very cohesion of the EU. The first few years after Fidesz' electoral victory in 2010 showed that the EU lacked both the legal instruments and the political will to deal with backsliding. The ultimate sanction suspension of important aspects of EU membership under the procedure laid out in Article 7 of the Treaty on European Union - required unanimity among the remaining member states. Ordinary mechanisms for dealing with states that break EU laws - the EU's infringement procedures - proved inadequate to restrain Fidesz's abuse of political power. Consequently, the Commission adopted the Rule of Law Framework in 2014, to deal with "systemic threats to the rule of law". Yet, in the absence of credible sanctions, this new policy tool failed the first time it was tested: Polish prime minister Beata Szydło simply dismissed the Commission's Recommendation as "incompatible with the interests of the Polish state" (Politico 2016; European Commission 2017). This prompted the inevitable question how long the EU can accept that member states systematically break the organization's laws and fundamental values.

Three broad strands of literature are relevant to the academic debates on backsliding in the $\mathrm{EU}$ and its consequences. The first is the comparative politics literature on democratization and democratic collapse. Here democratic backsliding is primarily a matter of dedemocratization: a process that reverses transitions to democracy or that initiates a transition away from democracy toward a more authoritarian (or hybrid) regime. The second strand is the EU public policy literature on the limits to Europeanization. Political parties that 
are set on democratic backsliding inevitably come into conflict with the EU's legal system when they weaken or dismantle domestic institutions that are protected by EU norms and laws. Before 2010, the literature on problems of implementation and compliance in the EU largely focused on problems of state capacity; but as the new Hungarian government's policies came up against the limits inherent in EU law, some researchers turned their attention to willful and deliberate non-implementation. The third relevant literature concerns the effects of democratic backsliding on the EU system. There is of course a longstanding literature on the limits of European integration, but as backsliding developed into a serious policy problem the old debates about the EU system's capacity to handle heterogeneity took on a new meaning and importance.

The present chapter is structured around four broad questions that are central to these research agendas. The first concerns the nature of democratic backsliding, defined here as $a$ gradual, deliberate, but open-ended process of de-democratization. In the EU context, this has some specific implications in terms of the notion that majority rule (as expressed in elections through representative parliaments) must be constrained by the rule of law (as determined by constitutions and interpreted by constitutional courts), and that democracy requires an independent civil society (free from excessive political appointments or interference). The second part turns to the question of why and how some, mainly postcommunist, member state governments have opted to weaken democracy. The answer lies in a combination of motive (ideology), opportunity (limited domestic institutional constraints), and resources (EU funding is a resource for building oligarchy). The third section explores the reasons for the EU's limited ability to deal with backsliding, focusing on the question whether this lies primarily in lack of political will or lack of legal instruments. The concluding section assesses the challenges that the EU'S crisis of democratic backsliding might present for the future of European integration.

\section{Defining Democratic Backsliding in the EU}

Democratic backsliding in the European Union became a salient topic for both researchers and policy practitioners in the second decade of the millennium both because some member states began to pursue policies that contravened their commitments to democracy and the rule of law, and because the EU came across as poorly equipped to deal with democratic backsliding. Yet there is no clear consensus on how to define democratic backsliding. The comparative politics literature can be divided into three somewhat distinct approaches to backsliding: analyzing it as a process that halts or reverses democratization; as an ideological alternative to liberal democracy; or in terms of bad governance.

The notion of backsliding as a process draws on the literature on democratic transition and consolidation, and involves analysis of dynamics that might halt or reverse these processes. The early literature on democratic backsliding dealt mostly with hybrid regimes outside Europe (Haggard and Kaufman 1995, Carothers 1999, Colton and Skach 2005); but the question of backsliding in the EU began to draw attention after the 2004 enlargement (Gati 
2007; Krastev 2007; Rupnik 2007; Jenne and Mudde 2012; Sedelmeier 2014, 2017; Ágh 2015; Iusmen 2015; Batory 2016a, Dawson and Hanley 2016; Kelemen 2017). With Donald Trump's victory in the 2016 presidential elections, it even turned to the USA (Mickey et al 2017). This literature is very much part of a broader literature on the decline of democracy (e.g. Merkel 2004, 2010; Fukuyama 2014; Diamond and Plattner 2015). Key features include decline in the rule of law and democratic practices, as well as concentration of political, social and economic power. This covers developments that weaken either of the key elements of liberal democracy, notably the rule of law. Indeed, since political parties must win power before they can embark on backsliding, attacks on an independent judiciary that represent a constraint on the elected government quickly became the hallmark of democratic backsliding in the EU (Scheppele 2014; Müller 2015; Sitter et al 2016, 2017).

The notion of backsliding as a normative alternative to liberal democracy is linked to the classic 'democratic dilemma' discussed by Robert Dahl (1956): the difficult balance between majority rule and minority rights. Orbán's advocacy of an 'illiberal state' (Prime Minister's Office [Hungary] 2014) as an alternative to the liberal democratic model draws on the populist tenet that the true representatives of the people should rule more or less unconstrained. As Cas Mudde (2015, see also 2016) put it, populism of this kind represented "an illiberal democratic response to undemocratic liberalism". This illiberal approach to democracy questions the importance of independent media, civil society and the concept of separation of powers, inasmuch as the role of all organizations should be to support the executive. To be sure, an 'illiberal state' might be compatible with what Wolfgang Merkel (2018) calls a minimalist approach to democracy, or even a Schumpeterian (1942) approach to democracy based on competitive elections. But when Angela Merkel told Orbán that she "can't understand what is meant by illiberal when it comes to democracy" (EUobserver 2015), the German chancellor drove home the point that in the European Union, democracy means liberal democracy.

A third set of scholars have focused on backsliding in terms of 'bad governance'. This is very much the reverse of the debates about good governance. One of the clearest definitions of backsliding comes from this literature: in his study of Malawi Lars Svåsand (2011) used backsliding to mean a decline in good governance, i.e. the opposite of democratization (a steady improvement in democratic governance). Some of this literature stretches the concept somewhat, by invoking what Merkel (2018) labels 'thick' definitions of democracy, including transparent and participatory processes, or even policy outcomes in terms of for example economic and social performance (Gati 2007; Krastev 2007), human rights (Guzman and Linos 2014) or migration (Levitz and Pop-Eleches 2010). In this context Béla Greskovits' distinction between 'hollowing out' of democracy and backsliding offers a pragmatic delineation of how far the concept can be usefully stretched: backsliding is "destabilization or even a reversal in the direction of democratic development" (2015:28-29). By contrast, Peter Mair's posthumous Ruling the Void is more about the hollowing out than backsliding. Parties that are so weak that they "no longer seem capable of sustaining democracy in its present form" (Mair 2013:1) can be a cause of backsliding, but hollowing out is not the same as democratic reversal. Likewise, corruption, rent seeking, abuse of public procurement, and 
oligarchical rule can be the causes and/or consequences of backsliding, but do not in themselves constitute backsliding.

Drawing on these three sets of literature, backsliding can be defined as a process of deliberate, intended actions on the part of a democratically elected government, designed to gradually undermine the fundamental rules of the game in an existing democracy (see also Bakke and Sitter 2019). This captures the key features in the literature on democratic reversal: backsliding is about a process, and it takes a country in the reverse direction of democratization (Waldner and Lust 2018). An additional caveat here is that democratic backsliding starts from a democratic system, and involves transition toward to a less democratic regime (Bermeo 2016). At the same time, this definition captures the role of political actors that is central to the literature on illiberal populism as a normative alternative to liberal democracy: backsliding is a deliberate policy choice, much in the same way that democratization involved clear choices (O'Donnell et al 1986; Linz and Stepan 1996). Finally, it limits the scope to policies that affect the key rules of the game.

In the EU context, the first key point is that the study of democratic backsliding is the study of why and how governments put in place reforms that weaken existing democratic institutions, including separation of political power, the role and scope of independent institutions (notably the judiciary), freedom of the press and of organization and assembly, and of course free and fair elections. Indeed, as far as EU member states are concerned, the commitment to liberal democracy is elaborated in the Treaty on European Union:

- In the Treaty Preamble, the signatories confirm "their attachment to the principles of liberty, democracy and respect for human rights and fundamental freedoms and of the rule of law".

- Article 2 states that "The Union is founded on the values of respect for human dignity, freedom, democracy, equality, the rule of law and respect for human rights, including the rights of persons belonging to minorities."

- Article 7 establishes the procedure for dealing with breaches of the values set out in Article 2, including the possibility of suspending some of the rights that a state derives from EU membership (most importantly, voting rights).

In addition, the Copenhagen Criteria require that a candidate country must achieve, among other things, stability of institutions guaranteeing democracy, the rule of law, human rights and respect for and protection of minorities. Consequently, if an EU state backslides, it does so from a liberal democratic starting point. Equally important, it does so as part of a deliberate, intentional process, not by accident.

Figure 1 Democratic backsliding in East Central Europe, 2004-2018 


\section{Freedom House}

Freedom in the World. Range 1-7, inverted scale

0

200420052006200720082009201020112012201320142015201620172018

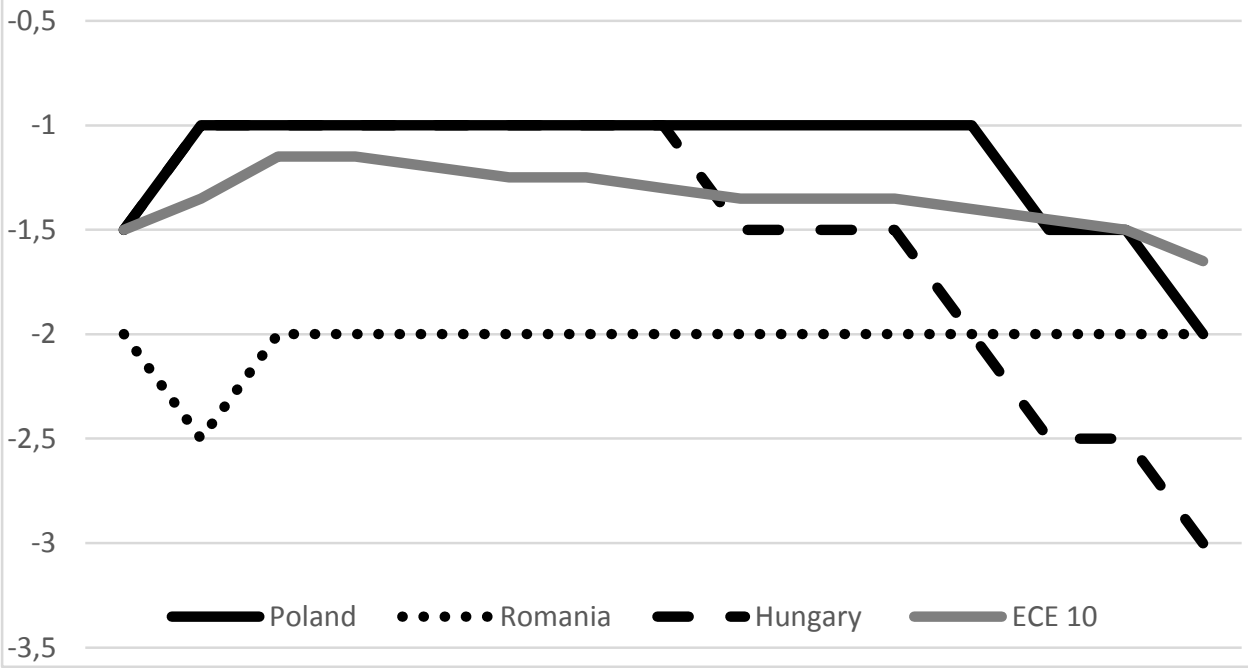

Figure 2 Rates of democratic backsliding in East Central Europe, 2010-2018

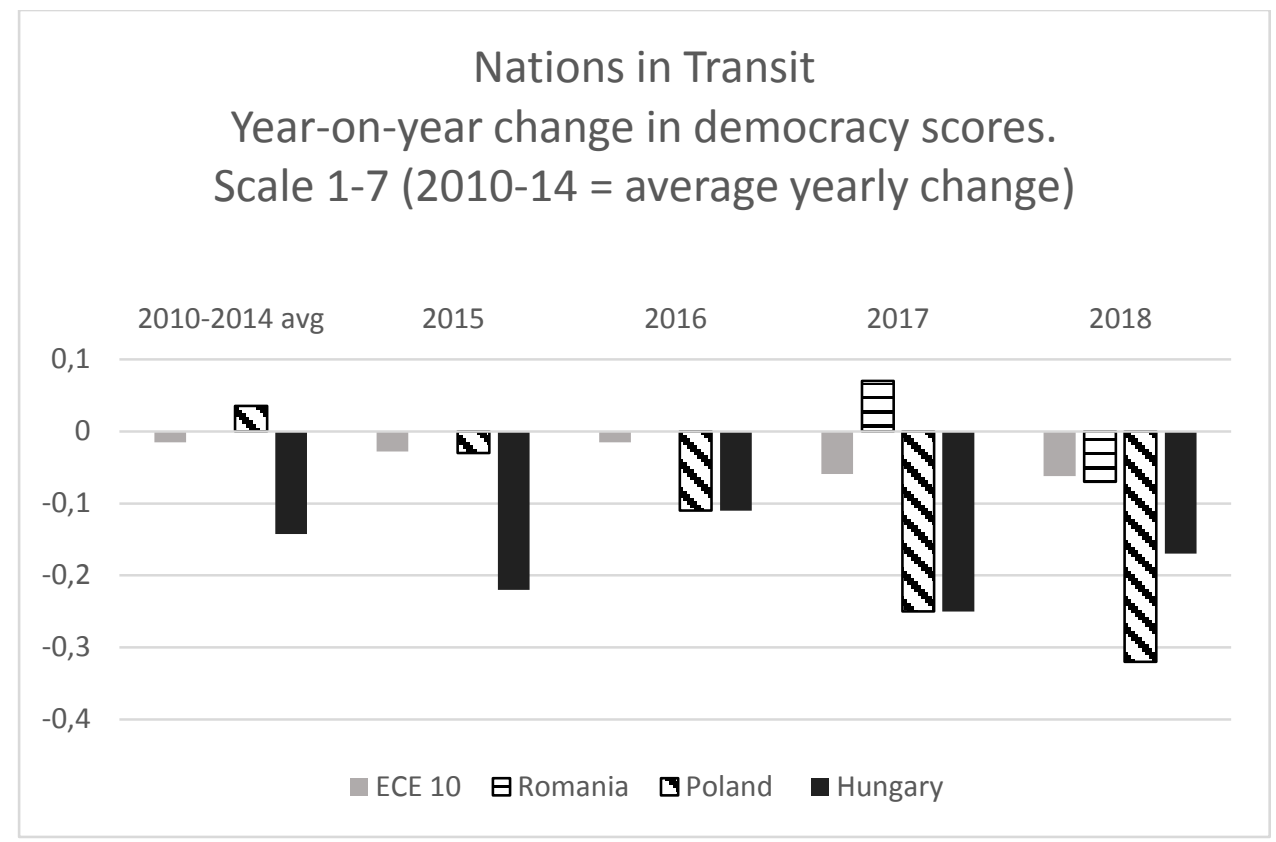

The second key point is that backsliding must be analyzed as a gradual process, not an all-ornothing break with liberal democracy. Indeed, this is how democracy indexes treat both democratization and its reversal, for example Freedom House's influential Nations in Transit and Freedom in the World index (see figures 1 and 2). In February 2019, Hungary became the first EU member state ever to lose its status as "Free", when Freedom House downgraded it to Partially Free because of "sustained attacks on the country's democratic institutions by 
Prime Minister Viktor Orbán's Fidesz party, which has used its parliamentary supermajority to impose restrictions on or assert control over the opposition, the media, religious groups, academia, NGOs, the courts, asylum seekers, and the private sector since 2010" (Freedom House, 2019).

There is a big difference between backsliding as a process, and the much more abrupt and dramatic change that a coup d'état would bring about. Paradoxically the EU Treaties were written more with the latter in mind: the Article 7 procedure requires such a high threshold (unanimity among the non-offending governments) as to be impossible to use in all but the most dramatic of cases; whereas the now famous Article 50 was originally written to allow authoritarian governments a quick exit from the EU (Politico 2017). Herein lies the key challenge for the European Commission, Parliament, and Council: If backsliding is gradual, determining when and where there is a serious and persistent breach of Article 2 values is likely to be controversial.

Third, and finally, democratic backsliding is by its very nature an open-ended process. The concept is not defined by a goal, but by a process. The extent to which backsliding undermines democracy, or even goes so far that the state in question is better described as a hybrid regime, is a matter of the consequences of backsliding. Regarding backsliding as an open-ended process, rather than an outcome, has clear policy implications in the sense that it can be reversed. Indeed, the 2014 Rule of Law Framework envisages EU action forcing the offending member state to reverse its backsliding course, either by force of persuasion or by threat of eventual sanctions. The Framework established a three-stage process, designed as a dialogue between the Commission and the member state in question. The first step involves the Commission assessing the problem, and if necessary issuing a Rule of Law Opinion. At the second stage, if the matter is not resolved, the Commission can issue a Rule of Law Recommendation, including a deadline for remedies. Finally, as a third stage, the Commission could initiate the Article 7 procedure.

The academic literature on democratic backsliding and EU decision-makers' efforts to ensure that member states remain democratic are thus complementary when it comes to defining democratic backsliding. Both from an analytical perspective and a policy perspective it makes sense to define democratic backsliding in the EU in terms of a democratic starting point, a gradual process and intentional government policy.

\section{The Dynamics of Democratic Backsliding in the EU}

Democratic backsliding is a strategy, not an accident. It involves a raft of measures, including centralization of political power, control of the state apparatus, management of the electoral process, and the weakening of independent media and civil society. These are not the by-product of other policies, let alone unintended consequences. They are policy goals. Moreover, such goals are incompatible with the commitments to liberal democracy that EU member states have made, both implicitly and explicitly. Consequently, any government that 
pursues a strategy of backsliding and at the same time seeks to maintain the benefits of EU membership, must adopt tactics that do not provoke too much of a reaction in the EU. The next section turns to how and why some member states were permitted to pursue backsliding more and more openly over the second decade of the millennium; but first the following paragraphs address the domestic dynamics of democratic backsliding.

If backsliding is a deliberate policy, it requires a motive. Tolstoy's Anna Karenina line about all happy families being alike and each unhappy family being unhappy in its own way could be applied to backsliding governments as well. Whereas backsliding projects like that of Jarosław Kaczyński seem to be driven primarily by populist, anti-EU ideology (Szczerbiak 2017); Ponta and Orbán's projects are sometimes assessed as more ideologically flexible, pragmatic efforts at capturing and maintaining power for powers sake, possibly with an element of rivalry between the leading personalities thrown in (Perju 2015; Lendvai 2018). The key point here is that backsliding does require some sort of motive, but the three prominent EU cases suggest that there is little common ideological ground beyond illiberal populism. In Orbán's case, illiberal populism and backsliding seems to be two sides of the same coin, rather than cause and effect. As Péter Krekó and Zsolt Enyedi put it, Orbán's approach to politics is based on the prime minister's personal clientelist network and his aspiration to "polarize and divide the electorate while retaining the support of the biggest and best-organized group within it" (2018: 43).

If democratic backsliding means that the point of departure is a democracy, then the second prerequisite for democratic backsliding is executive power. The existing rules of the game are the main factor that shapes a newly elected government's opportunity for centralization of power (Bakke and Sitter 2019). In 1990, Hungary's requirement for a two-thirds majority in parliament to change the constitution might have seemed a reasonable safeguard. However, as early as in 1994, the country's semi-majoritarian electoral system returned a coalition with such a majority (it opted not to abuse this power). When Fidesz won a supermajority with 53 per cent of the vote in 2010, the party was free to re-write the rules of the game. To be sure, even with an ordinary majority the party would have been able to elect the president, and put in place many of its backsliding measures. This is exactly what PiS did in late 2015, with the help of a friendly president in the shape of Andrzej Duda (directly elected five months earlier). However, unlike Fidesz, PiS could not cajole the Constitutional Court with threats to rewrite the constitution.

The Hungarian case suggests that one of the most urgent tasks for a newly elected government set on centralization of political power is to ensure that the executive dominates the legislature. Some of Fidesz' measures in 2010-14 provide good examples, including the use of legislative procures that curtail consultation, debate and scrutiny of parliamentary legislation. Even a constitutional amendment was submitted as a private member's bill (Halmai and Scheppele 2013:3). Poland used similar instruments to limit NGOs' access to public funds and to criminalize discussions of Polish individuals' role in the Holocaust (Helsinki Foundation [Poland] 2017). In Romania, the measures that prompted EU intervention in 2012 included both Ponta's effort to remove the president and to circumvent 
the Constitutional Court's rulings by limiting its competence. However, the fact that Romania (like Bulgaria, but unlike Poland and Hungary) was still subject to the EU's Cooperation and Verification procedure gave the Commission more leverage (by way of not closing the procedure).

The most controversial measures, in all three cases, were the policies designed to limit judicial independence. This includes the early retirement of judges in Hungary in 2011: the government terminated the term of the president of the Supreme Court and lowered the compulsory retirement age for judges from 70 to 62, thus opening the way for 274 new appointments. The Commission opted for infringement procedures based on labour law, and forced the government to pay compensation to the judges. But the new judges appointed by Fidesz remained in place (Batory 2016b). In Poland PiS began its tenure in 2015 by annulling Constitutional Court appointments. In both cases, parliament passed laws that limited the scope of the constitutional court; in the Polish case this led to a constitutional crisis and a Rule of Law recommendation by the Commission (2017; see also Venice Commission 2016). Efforts to control the state apparatus can of course also involve other 'arms-length' agencies of the state, such as the national audit office and regulatory authorities. Matthijs Bogaard's assessment of Hungary as "a diffusely defective democracy" (2018) is a case in point: it includes quantitative indicators of both the political process and government capture of the wider state machinery.

Fidesz' two-thirds majority in parliament (which it maintained for much of the 2010-19 period) gave the Hungarian government a much more powerful tool than its Romanian and Polish counterparts. Through the combination of a new constitution, subsequent constitutional amendments, and 'Cardinal Laws' which can only be changed by a $2 / 3$ majority, Fidesz was able to lock-in its policy and personnel preferences for the foreseeable future - even in the event of a loss of power. This drew sharp criticism from the Commission and the European Parliament, but was ambiguous enough that Fidesz' allies in the European People's Party hesitated to criticize their sister party (see the next section, below).

One of the defining features of democratic backsliding is that it maintains some elements of liberal democracy - notably competitive elections. Banning opposition parties or suspending elections would clearly be incompatible with Article 2; and analytically it would take us into the realm of unambiguous authoritarianism. Electoral reform, on the other hand, is a regular occurrence in most liberal democracies, and it usually favors the mainstream political parties (Lijphart 1994). In Italy and France, some electoral reforms have even been designed explicitly to help the incumbent government win re-election. However, of the EU backsliding cases, only the Hungarian government has had the power unilaterally to change the electoral law, district boundaries, and campaign rules, as well as control the electoral commission. The OSCE report on the 2014 elections concluded that: "The main governing party enjoyed an undue advantage because of restrictive campaign regulations, biased media coverage and campaign activities that blurred the separation between political party and the State" (OSCE 2014:3) 
Finally, unlike the classic authoritarian recipe (which involves eliminating opposition), the illiberal backsliding approach involves limiting or marginalizing independent voices. In Hungary and Poland Fidesz and PiS used a mix of direct management of state media (including dismissing or forcing out critical journalists), oligarchic ownership, and directing state advertising and subsidies to pro-government media, causing Freedom House (2017) to assess both as only "Partly Free" in terms of press freedom in 2016. In Hungary that year, the leading opposition paper Népszabadság was closed down after a take-over. The last remaining opposition daily of any stature, Magyar Nemzet, which turned against Fidesz in 2015, folded after the 2018 election (and was resurrected as a pro-government daily in 2019).

The first attack on independent civil society organizations that caused international controversy came when the Hungarian government changed the regime for overseeing EUrelated funding from Norway (not an EU member, but a 'quasi-member' by way of the European Economic Area), and raided the NGO tasked with distributing the grants. The Norwegian government interpreted this as breach of the rules for the EEA and Norway Grants, and suspended all funding. The Hungarian government eventually backed down, and accepted all the conditions set by the Norwegian government (Ministry of Foreign Affairs [Norway] 2014, 2015). However, the campaign against civil society intensified in 2017 and 2018, forcing the Open Society Foundations and Central European University to leave Budapest for Berlin and Vienna, respectively. The EEA Grants round for 2014-21 was still "under negotiation" for Hungary as of March 2019 (Ministry of Foreign Affairs [Norway], 2019). In Poland, the turn toward 'illiberal democracy' hit civil society in 2016. New laws that limited NGOs access to public funds, and criminalized discussions of Polish individuals' role in the Holocaust were widely criticized (Helsinki Foundation [Poland] 2017).

The Polish and Hungarian cases suggest that there is no single motive or recipe for democratic backsliding in the European Union. Backsliding can be driven primarily by ideology, or a more pragmatic quest for power. In reality, the two motives probably reinforce each other: the more a populist government turns illiberal, the more it backslides; and the more a government seeks to dismantle checks and balances that limit its power, the more illiberal it becomes. The most important common elements in the two cases dovetail nicely with democratic theory. Liberal democracy requires the rule of law, free and fair elections, independent institutions, civil society and media. The first targets of Fidesz and PiS were the judiciary (and other independent state agencies), the media and civil society; and in the Hungarian case (because Fidesz had the necessary power) also the constitution and the electoral system. The big question is why the European Union did little or nothing to stop this.

\section{Democratic Backsliding and EU Crisis Management}


Given that democratic backsliding in Poland and Hungary directly contravened the norms and rules laid down the EU Treaty, why were the EU institutions unable to halt or reverse democratic backsliding? To be sure, part of the answer is that the EU did in fact have a constraining effect on backsliding in Poland and Hungary. Even with all the caveats that apply to counter-factual analysis, PiS and Fidesz' illiberal populist rhetoric can be taken as evidence that both governments would ideally have gone much further in terms of dismantling liberal democracy had it not been for the fear of EU censure. Nevertheless, both countries had managed to backslide considerably by 2019 , with few serious consequences. If democratic backsliding represented a potential crisis for the EU, the literature on crisis management points to two main possible reasons for this failure - lack of policy tools and lack of political will (Cabane and Lodge 2017).

The problem was not that the EU had not anticipated that it might one day experience problems with respect to one of its member's commitments to liberal democracy. The Copenhagen Criteria for EU membership were laid down in 1993 with this in mind, and two events in the second half of the 1990s drove the point home. The first was when Vladimír Mečiar's national populist government took control of state media and set out to centralize executive power by installing its own people in key positions, limiting the opposition's opportunity to take part in law-making, unlawfully stripping a defecting MP of his mandate, stripping the president of powers not granted by the constitution and slashing his budget and staff (see e.g. Krno et al 2009). The Commission (1997:130) responded quickly and in clear language, and relegated Slovakia to the 'slow lane' of EU applicant states: "Slovakia does not fulfil in a satisfying manner the political conditions set out by the European Council in Copenhagen, because of the instability of Slovakia's institutions, their lack of rootedness in political life and the shortcomings in the functioning of its democracy." Only after a change of government in 1998, when a broad anti-Mečiar coalition won the election, did the Commission proceed to recommend negotiations with Slovakia.

The second warning signal came after Austrian elections of October 1999, when the far-right Austrian Freedom Party (FPÖ) joined the conservative Austrian People's Party (ÖVP) in government (Merlingen, Mudde and Sedelmeier 2001). The other 14 member states were at a loss to how to respond, and ended up with a combination of bilateral boycotts of the Austrian government and a committee of three 'wise men' assigned to keep an eye on developments. In September 2000 these measures were ended. But the provisions that became Article 7 were written into the Treaty, first in Amsterdam in 1997, and then in a stronger form in Lisbon in 2007 (Sadurski 2010).

The main problem with Article 7 was that it constituted a 'nuclear option' in the sense that suspending elements of a state's membership is a dramatic measure that many states might be reluctant even to consider (Müller 2013; Sedelmeier 2017). Although the process can be launched by the Parliament, the Commission or one third of the member states, the threshold for invoking Article 7 is high: Determining that there is 'is a clear risk of a serious breach' of Article 2 values requires a four-fifths vote in the Council (i.e. 22 of the remaining 27 states in a 28-state EU) and the support of Parliament. Determining the actual 'existence 
of a serious and persistent breach' requires unanimity in the European Council. Unless there is a case of democratic backsliding that is so unambiguous and severe that the rest of the member states all agree that action must be taken, the EU's measures to deal with backsliding are reduced to ordinary infringement procedures or the 'soft power' of persuasion.

The issue of political will is problematic for several reasons: some governments see this as the EU overstepping its legitimate authority, others fear that they could be next in line, and some governments may be internally divided on the matter. This became clear in the wake of the Commission triggering Article 7 proceedings against Poland on 20 December 2017, after exhausting the procedure laid down in the Rule of Law framework. The Commission's conclusions were unambiguous: "there is a clear risk of a serious breach of the rule of law in Poland" (European Commission 2017). However, when the member state EU ambassadors voted informally six months later on whether to consider an Article 7 move, barely half of the member states were prepared even to consider that there might be a 'clear risk of a serious breach'. Hungary, the Czech Republic, Slovakia and Croatia voted against, while Austria, Romania, Italy, Lithuania, Malta, Estonia, Slovenia, the UK and Bulgaria all abstained (Financial Times 2017). In any case, the Hungarian government promised to veto any sanctions against Poland.

The problem of political will, or rather reluctance to censure a backsliding government, is as much a problem for political parties as for states. For example, when in 2013 the (liberal) foreign ministers of Denmark, Finland, Germany and the Netherlands wrote a joint letter calling for new measures to deal with states that violated fundamental EU democratic values, Sweden's (conservative) foreign minister declined to join them even in implicit criticism of a government run by a fellow member of the European People's Party (Dagens Nyheter 2013). In the European Parliament, a substantial part of the EPP abstained or voted against negative reports on democratic backsliding in the EU, including the Tavares (2013) and Sargentini (2018) reports. Indeed, the question of whether Fidesz ought to be expelled from the EPP cast a shadow over the contest between Manfred Weber and Alex Stubb in the 2018 EPP Spitzenkandidat primary election. Considering party loyalty, it was perhaps not surprising that both the Parliament and the Commission were prepared to move more dramatically against the PiS government, which did not enjoy the protection of a major party group (indeed, PiS biggest rival, the Civic Platform, was an EPP member).

The Commission adopted a cautions two-track strategy with regard to Hungary, combining political pressure with ordinary infringement procedures. Although Barroso and Reding openly criticised Orbán, the Commission dealt with the problems related to the 2010 media law as a matter of ordinary infringement related to the transposition of a media-related directive, not a rule-of-law matter, and a crisis was averted when the Hungarian government backed down. It took a similar approach to the above-mentioned case of judges' early retirement, thus permitting Fidesz to develop a strategy of 'creative compliance' (Batory 2014, 2016a). At the same time, the political pressure continued, and was captured elegantly in Commission President Jean-Claude Juncker's greeting the Hungarian Prime Minister with a 
jovial "Hello, Dictator" at the 2015 Riga Summit. Reding defended the Commission's strategy by arguing "I prevented worse [...] It did not change dramatically the nationalistic course of the Hungarian prime minister, but at least it stopped him dismantling the independence of the courts and the independent data authority" (Reuters 2015).

There were of course other good reasons for the EU's more assertive moves against Poland than Hungary. In the first few years, Victor Orbán's posturing could be dismissed as hype rather than substance. By the time PiS took over in Poland five years later, the Hungarian case was more serious, and backsliding began to look like a pattern in the EU. Once (Slovakia in the 1990s) could be an accident, twice (Hungary in 2010) a coincidence, but by 2015 three times was beginning to look like a pattern. In addition, geopolitics and history meant that no Polish government could hint - as Orbán did - that too harsh a response from the EU might drive the country into the open arms of Vladimir Putin (Sitter et al 2017). In the end it was the European Parliament that triggered Article 7 against Hungary, meeting the required twothirds threshold when adopting the Sargentini report by 448 to 197 votes on 12 September 2018.

The EU is sometimes held up as the guarantor of its member states' commitments to democracy and freedom. The relegation of Slovakia to the second tier of applicant states in 1997 may have helped motivate the opposition to mobilize against Mečiar, but this was at best an indirect effect. When it comes to democratic backsliding in an EU member state, the EU's toolbox is much weaker. The Polish case shows that, even with the new Rule of Law Framework, the Commission's tools ultimately come down to the credibility of Article 7. Although EU action did have an effect in Romania in 2012, the much more severe Hungarian and Polish cases suggest that the EU lacks both the political will and the policy tools to deal with backsliding. Yet the case of the confrontation between Hungary and Norway suggest that the 'power of the purse' might be more effective than normative pressure or threats of unrealistic Article 7 sanctions. Indeed, at the time of writing (March 2019) the Commission had just won support from the European Parliament for proposals to develop a new mechanism for linking EU funding to the rule of law (European Parliament 2019). This proposal for a regulation On the protection of the Union's budget in case of generalised deficiencies as regards the rule of law in the Member States was part of the EU's seven-year budget package, the 2021-2027 Multiannual Financial Framework. Given that the adoption of the MFF requires unanimity in the Council, and many of the north-western net contributor states' exasperation with backsliding among some net beneficiaries, the stage was set for continued and more open confrontation over democratic backsliding in the EU.

\section{Does Democratic Backsliding in the EU Matter?}

From a liberal democratic normative perspective, democratic backsliding is a problem both for the member states in which it takes place and for the EU. If democratic backsliding is defined as a process of deliberate, intended actions on the part of a democratically elected government, designed to gradually undermine the fundamental rules of the game in an 
existing democracy, both PiS in Poland and Fidesz in Hungary qualify. Both have had the first step of Article 7 proceedings triggered against them, the former by the Commission and the latter by the European Parliament. But as of early 2019, both looked safe from being deemed in 'risk of a serious breach' of Article 2 values by their fellow governments, let alone to be found to have actually violated said values. As debates about new, funding-linked mechanisms to protect the rule of law came underway, perhaps the most important question was whether democratic backsliding in the EU matters for the future of the organisation.

The EU can choose between three broad strategies for dealing with the challenge for democratic backsliding: containing it, accepting it, or reversing it. Between 2010 and 2016, the European Commission, Parliament and most of the member state governments focused their efforts to contain democratic backsliding. The Romanian 2012 episode was encouraging in this respect, and reinforced the earlier lessons from Austria and Slovakia to the effect that the EU could, through measured action and clear normative signals, contain backsliding and maintain pressure on the states in question until the natural alternation in government brought a more reasonable party or coalition to power. By 2019, this strategy seems much less promising, both with respect to Poland and Hungary. Indeed, in the run-up to the 2019 European elections, the PiS began to build alliances with Italy's Lega, with a view to increasing the right-populist presence in the European Parliament, and perhaps even tip the balance in favor of accommodating democratic backsliding. The notion that the EU could contain and out-wait backsliding governments lost currency.

The alternatives are to accept backsliding or to fight it. Both involve potential problems for the European Union. Tolerating open defiance of EU law might lead to a de facto differentiated EU, where some states do not recognize another state's legal system as competent. In June 2018, the Court of Justice of the European Union (2018) made a landmark ruling to the effect that Ireland could block an extradition under the European Arrest Warrant if there was "a real risk that the individual concerned would suffer a breach of his fundamental right to an independent tribunal" (2018). In addition, the notion that EU funding might represent a new variant of the classic 'resource curse' (oil as a source of rentseeking) that sustained oligarchy and backsliding got some traction (Bozóki and Hegedús 2018). During 2017 and 2018, in the run-up to the next round of MFF negotiations, several north-western governments indicated that they would not be prepared to continue to contribute to the EU budget unless EU-funding was linked to compliance. In short, a strategy based on accepting backsliding could end up undermining the cohesion of the EU from within.

On the other hand, a strategy designed to reverse backsliding must in the end be based on the threat of using Article 7. Setting aside the question of whether the EU could muster the political will to embark on such as strategy, the biggest potential problem is that such measures might force backsliding states out of the EU altogether - perhaps into closer alignment with autocracies like Russia or Turkey. If the fundamental purpose of the organization is the pursuit of wealth, peace, freedom, and democracy, the problem is that a 
smaller and more cohesive EU is not necessarily a more secure EU. A milder form of sanctions, linked to reduction or suspension of EU funding, might have better prospects of success. However, if the Commission were to be granted the power to use such an instrument without unanimous consent from the (non-offending) member state governments, and it were to use this repeatedly, the danger of a two-tier EU could be back on the agenda. Consequently, the EU faces a genuine policy dilemma when it comes to how to deal with democratic backsliding. Too little action could undermine the EU from within; too much could cause the EU to split. As of early 2019, the EU's main challenges were related to Poland and Hungary. But the question looming on the horizon was whether, if left unchecked, democratic backsliding might develop into a systemic crisis for the EU. 


\section{References (all links accessed 7 Feb 2019)}

Ágh, Atila (2015), “De-Europeanization and De-democratization Trends in ECE: From the Potemkin Democracy to the Elected Autocracy in Hungary", Journal of Comparative Politics, $8: 2(2015), 4-26$.

Bakke, Elisabeth and Nick Sitter (2019), "Why institutions Matter: Democratic Backsliding in Central Europe", presented at den nasjonale fagkonferansen i statsvitskap, NTNU, Trondheim, 7-9 Jan 2019.

Batory, Agnes (2014), “Uploading as political strategy: the European Parliament and the Hungarian media law debate", East European Politics, 30:2, 230-245.

Batory, Agnes (2016a), "Populists in government? Hungary's "system of national cooperation"', Democratization, 23:2, 283-303.

Batory, Agnes (2016b), "Defying the Commission: Creative Compliance and Respect for the Rule of Law in the EU", Public Administration, 94: 3, 685-699.

Bermeo, Nancy (2016), “On Democratic Backsliding”, Journal of Democracy, 27:1, 5-19.

Bogaard, Matthijs (2018), "De-democratization in Hungary: diffusely defective democracy", Democratization, 25:8, 1481-1499.

Bozóki, András and Dániel Hegedűs (2018), “An externally constrained hybrid regime: Hungary in the European Union", Democratization, 25:7, 1173-1189.

Cabane, Lydie and Martin Lodge (2017), Dealing with Transboundary Crises in the European Union: Options for enhancing effective and legitimate transboundary crisis management capacities, TransCrisis White Paper https://www.transcrisis.eu/wp-content/uploads/2018/02/TransCrisis-White-Paper.pdf

Carothers, Thomas (2007), 'A Quarter Century of Promoting Democracy', Journal of Democracy, 18(4): 113-123.

Colton, Timothy J. and Cindy Skach, "A Fresh Look at Semipresidentialism: The Russian Predicament", Journal of Democracy, 16:3, 113-126.

Court of Justice of the European Union (2018), Judgment in Case C-216/18 PPU, https://curia.europa.eu/jcms/upload/docs/application/pdf/2018-07/cp180113en.pdf

Dagens Nyheter (2013), "Sveriges pinsamma tystnad", 13 March 2013, https://www.dn.se/ledare/huvudledare/sveriges-pinsamma-tystnad/ 
Dahl, Robert (1956) A Preface to Democratic Theory, Chicago: The University of Chicago Press.

Dawson, James and Seán Hanley (2016), "East Central Europe: The Fading Mirage of the 'Liberal Consensus'”, Journal of Democracy, 27:1, 20-34.

Diamond, Larry and Marc F. Plattner (2015), Democracy in Decline, Baltimore, MD: Johns Hopkins University Press.

EUobserver (2015), "Merkel clashes with Orban on meaning of 'democracy'” 3 Feb 2015, https://euobserver.com/beyond-brussels/127468

European Commission (1997), “Agenda 2000 - Commission Opinion on Slovakia's Application for Membership of the European Union", 16 July, 1997, https://www.esiweb.org/pdf/slovakia EC\%200pinion\%20on\%20SK\%201997 en.pdf

European Commission (2017), European Commission Press Release IP-16-2643 "Rule of Law: Commission issues recommendation to Poland" 27 July 2017, http://europa.eu/rapid/pressrelease_IP-16-2643_en.htm.

European Parliament (2019), Protection of the Union's budget in case of generalised deficiencies as regards the rule of law in the Member States, P8_TA-PROV(2019)0038, 17 Jan 2019, http://www.europarl.europa.eu/sides/getDoc.do?pubRef=-//EP//NONSGML+TA+P8TA-2019-0038+0+DOC+PDF+VO//EN

Financial Times (2017), "Brussels heads for showdown with Poland over rule of law", Financial Times, 18 June 2018. https://www.ft.com/content/0cec19ae-70bc-11e8-92d3$\underline{6 c 13 e 5 c 92914}$

Freedom House (2017), Freedom of the Press 2017, https://freedomhouse.org/sites/default/files/FOTP 2017 booklet FINAL April28.pdf Hungary Profile, https://freedomhouse.org/report/freedom-press/2017/hungary Poland Profile, https://freedomhouse.org/report/freedom-press/2017/poland

Freedom House (2019), Freedom in the World 2019, https://freedomhouse.org/report/freedom-world/freedom-world-2019

Fukuyama, Francis, (2014), Political Order and Political Decay: From the Industrial Revolution to the Globalization of Democracy, New York, NY: Farrar, Straus and Girouz.

Gati, Charles(2007), "Backsliding in Central and Eastern Europe”, The Quarterly Journal, Fall 2007, 107-120. 
Greskovits, Béla (2015), "The Hollowing and Backsliding of Democracy in East Central Europe", Global Policy, 6:1, 28-37.

Guzman, Andrew T. and Katerina Linos (2014), "Human Rights Backsliding", California Law Review, 102, 603-654.

Halmai, Gábor and Kim Lane Scheppele (eds.) (2012), Opinion on Hungary's New Constitutional Order: Amicus Brief for the Venice Commission on the Transitional Provisions of the Fundamental Law and the Key Cardinal Laws.

https://lapa.princeton.edu/hosteddocs/hungary/Amicus_Cardinal_Laws_final.pdf

Haggard, Stephan and Robert R. Kaufman (1995), The Political Economy of Democratic Transitions, Princeton, NJ: Princeton University Press.

Helsinki Foundation [Poland] for (2017), The Situation of Civil Society Organisations in Poland, Helsinki Foundation for HumanRights, Warsaw, http://www.hfhr.pl/wpcontent/uploads/2017/09/HFHR_situation_ngos_in_Poland_brief.pdf

lusmen, Ingi (2015), "EU Leverage and Democratic Backsliding in Central and Eastern Europe: the Case of Romania", Journal of Common Market Studies, 53:3. 593-608.

Jenne, Erin and Cas Mudde (2010), "Hungary's Illiberal Turn: Can Outsiders Help?", Journal of Democracy, 23:3, 147-155.

Kelemen, R. Daniel (2017), “Europe's Other Democratic Deficit: National Authoritarianism in Europe's Democratic Union", Government and Opposition, 52:2, 211-238.

Krastev, Ivan (2007), "The Strange Death of the Liberal Consensus", Journal of Democracy, 18:4, 56-63.

Krekó, Péter and Zsolt Enyedi (2018), “Explaining Eastern Europe: Orbán's Laboratory of Illiberalism", Journal of Democracy, 29:3, 39-51.

Krno, Svetozár, Jozef Lysý, and Martin Krno (2009), "National Council from the dissolution of Czecho-Slovakia and the birth of the Slovak Republic until today", in Miroslav Pekník (ed.) Slovak National Councils and the Road to Parliamentarism, Bratislava: VEDA.

Lendvai, Paul (2018), Orbán: Hungary's Strongman, Oxford: Oxford University Press.

Levitz, Philip and Grigore Pop-Eleches (2010), "Monitoring, Money and Migrants: countering Post-Accession Backsliding in Bulgaria and Romania", Europe-Asia Studies, 62:3, 461-479.

Lijphart, Arend (1994), Electoral Systems and Party Systems: A Study of Twenty-Seven Democracies, 1945-1990, Oxford: Oxford University Press. 
Linz, Juan J. and Alfred Stepan (1996), Problems of Democratic Transition and Consolidation, Baltimore: Johns Hopkins University Press.

Mair, Peter (2013) Ruling the Void: The Hollowing of Western Democracy, London: Verso.

Merkel, Wolfgang (2004), "Embedded and Defective Democracies", Democratization, 11:5, 33-58.

Merkel, Wolfgang (2010), “Are dictatorships returning? Revisiting the 'democratic rollback' hypothesis", Contemporary Politics, 16:1, 17-31.

Merkel, Wolfgang (2018), "Challenge or Crisis of Democracy", in Wolfgang Merkel and Sascha Kneip (eds), Democracy and Crisis: Challenges in Turbulent Times, Wiesbaden: Springer International Publishing.

Michael Merlingen, Cas Mudde and Ulrich Sedelmeier (2001), "The Right and the Righteous? European Norms, Domestic Politics and the Sanctions Against Austria", Journal of Common Market Studies, 39:1, 59-77.

Mickey, Robert, Steven Levitsky and Lucan Ahmad Way (2017), 'Is America Still Safe for Democracy: Why the United States Is in Danger of Backsliding' Foreign Affairs, 96 (3): 20-29.

Ministry of Foreign Affairs [Norway] (2014) "Suspension of funds to Hungary" 3 Nov 2014 https://www.regjeringen.no/en/topics/european-policy/norwaygrants/diversesaker/Suspension-of-funds-to-Hungary/id2008980/

Ministry of Foreign Affairs [Norway] (2015) "Suspension of EEA and Norway Grants payments to Hungary lifted" 11 Dec 2015 https://www.regjeringen.no/en/aktuelt/suspension-of-eea-and-norway-grants-paymentsto-hungary-lifted/id2467020/

Ministry of Foreign Affairs [Norway] (2019), “Ungarn”, 19 March 2019, https://www.regjeringen.no/no/tema/europapolitikk/eos-midlene/mottagere-eosmidler/ungarn/id686858/

Mudde, Cas (2015), "The problem with populism", The Guardian, 17 Feb 2015, https://www.theguardian.com/commentisfree/2015/feb/17/problem-populism-syrizapodemos-dark-side-europe

Mudde, Cas (2016), Europe's Populist Surge: A Long Time in the Making, Foreign Affairs, 95 Nov/Dec, 25-30. 
Müller, Jan-Werner (2013), "Defending Democracy in the EU", Journal of Democracy, 24:2 Number 2, 138-149.

Müller, Jan-Werner (2015), "Should the EU Protect Democracy and the Rule of Law in Member States?" European Law Journal, 21:2, 141-160.

O’Donnell, Guillermo, Philippe C. Schmitter, and Laurence Whitehead (eds) (1986),

Transitions from Authoritarian Rule: Comparative Perspectives, Baltimore: The Johns Hopkins University Press.

OSCE (2018), Organization for Security and Co-operation in Europe Office for Democratic Institutions and Human Rights, "Hungary: Parliamentary Elections 6 April 2014",

OSCE/ODIHR Limited Election Observation Mission Final Report, Warsaw, 11 July 2014, https://www.osce.org/odihr/elections/hungary/121098

Perju, Vlad (2015), "The Romanian double executive and the 2012 constitutional crisis", International Journal of Constitutional Law, 13:1, 246-278.

Politico (2012,), “EU outcry over Romaina forces Ponta to retreat", Politico, 18 July 2012, https://www.politico.eu/article/eu-outcry-over-romania-forces-ponta-to-retreat/

Politico (2016), "Poland rejects Commission's rule of law request", 28 Nov 2016, https://www.politico.eu/article/beate-szydlo-eu-law-and-justice-poland-rejectscommissions-rule-of-law-request/

Politico (2017), “Article 50 author Lord Kerr: I didn't have UK in mind - The EU's divorce clause was designed amid concerns about a 'dictatorial regime'”, Politico, 28 March 2017, https://www.politico.eu/article/brexit-article-50-lord-kerr-john-kerr/

Prime Minister's Office [Hungary] (2014), “Prime Minister Viktor Orbán's Speech at the 25th Bálványos Summer Free University and Student Camp", 26 July 2014, Tusnádfürdő (Băile Tuşnad), Romania, http://www.kormany.hu/en/the-prime-minister/the-prime-minister-sspeeches/prime-minister-viktor-orban-s-speech-at-the-25th-balvanyos-summer-freeuniversity-and-student-camp

Reuters (2015), “Analysis - Despite 'hello dictator', EU struggles to curb Hungary's Orban”, 8 June 2015, https://uk.reuters.com/article/uk-hungary-eu-analysis/analysis-despite-hellodictator-eu-struggles-to-curb-hungarys-orban-idUKKBNOON09K20150608

Rupnik, Jacques (2007), "Is Central Europe Backsliding: From Democracy Fatigue to Populist Backlash", Journal of Democracy, 18:4, 17-25.

Sadurski, Wojceich (2010), “Adding Bite to a Bark: The Story of Article 7, E.U. Enlargement, and Jorg Haider", Columbia Journal of European Law, 16, 385-426. 
Sargentini, Judit (2018), Report on a proposal calling on the Council to determine, pursuant to Article 7(1) of the Treaty on European Union, the existence of a clear risk of a serious breach by Hungary of the values on which the Union is founded (2017/2131(INL)) http://www.europarl.europa.eu/sides/getDoc.do?pubRef=-//EP//NONSGML+REPORT+A82018-0250+0+DOC+PDF+V0//EN

Sedelmeier, Ulrich (2014), "Anchoring Democracy from Above? The European Union and Democratic Backsliding in Hungary and Romania after Accession", Journal of Common Market Studies, 52:1, 105-121.

Sedelmeier, Ulrich (2017), "Political safeguards against democratic backsliding in the EU: the limits of material sanctions and the scope of social pressure", Journal of European Public Policy, 24:3, 337-351.

Scheppele, Kim Lane (2014) "The Rule of Law and the Frankenstate: Why Governance Checklists Do Not Work", Governance, 26:4, 559-562.

Sitter, Nick, Agnes Batory, Joanna Kostka, Andrea Krizsan and Violetta Zentai (2016), Mapping Backsliding in the European Union, TransCrisis Policy Brief D.1, Budapest: Central European University.

Sitter, Nick, Agnes Batory, Andrea Krizsan and Violetta Zentai (2017) Backsliding in area of constitutional safeguards and independent institutions, corruption control, and general equality and minorities, TransCrisis Report 6.2., Budapest: Central European University.

Szczerbiak, Aleks (2016) "An anti-establishment backlash that shook up the party system? The October 2015 Polish parliamentary election" Perspectives on European Politics and Society, 18:4, 404-42.

Tavares, Rui (2013) Report on the situation of fundamental rights: standards and practices in Hungary (pursuant to the European Parliament resolution of 16 February 2012), (2012/2130(INI)), https://www.europarl.europa.eu/sides/getDoc.do?pubRef=//EP//NONSGML+REPORT+A7-2013-0229+0+DOC+PDF+V0//EN

Venice Commission (2016) European Commission for Democracy through Law (Venice Commission), Opinion no. 833/2015, "Opinion on amendments to the act of 25 June 2015 on the Constitutional Tribunal of Poland", 11 March 2016,

https://www.venice.coe.int/webforms/documents/default.aspx?pdffile=CDL-AD(2016)001-e

Waldner, David and Ellen Lust (2018), "Unwelcome Change: Coming to Terms with Democratic Backsliding”, Annual Review of Political Science, 21:93-113. 